\title{
MINIMUM WEIGHT OPTIMIZATION OF MATERIALS AND HIGH STRENGTH FOR SPUR GEAR DESIGN
}

\author{
KAREEM ABDULGHAFOUR ABDULLA ${ }^{1}$, SAFEEN YASEEN EZDEEN ${ }^{2} \&$ ALFONS AMS $^{3}$ \\ ${ }^{1,2}$ Department of Mechanical \& Mechatronics Engineering, College of Engineering, Salahaddin University-Erbil, Iraq \\ ${ }^{3}$ Faculity of Mechanical Engineering, Department of Mechanics \& Fluid Dynamic, Technical University Freiberg,
}

Freiberg, Germany

\begin{abstract}
The purpose of this research was to select the optimal materials for various spur gear designs. Three gears were designed using three variables: the number of teeth, the material weight constant, and the Lewis factor form. The objective function was set to minimize mass based on the restriction of bending fatigue failure criteria and bending strength. A variety of gear designs were carried out with/different types of materials by using MATLAB to demonstrate the variations between the weights of the parts. To verify the data from the spur gear design, numerical simulation was carried out by finite element analysis (FEA) using ANSYS R17. Lightweight and high-strength materials have been particularly recommended for the design of spur gears.
\end{abstract}

KEYWORDS: Lightweight Design, Spur Gear Design, Lewis Equation

Received: Jun 17 2021; Accepted: Jul 07, 2021; Published: Jul 19, 2021; Paper Id.: IJMPERDAUG202124

\section{INTRODUCTION}

Spur gear is the most basic and widely used type of gear. Higher load carrying capacity and improved fatigue life of gears are subjected to increased demand. Undercutting produces the tooth filet by extracting material from the profile of the involute with the tip of the cutter, resulting in teeth with less thickness at the root, where the crucial section is normally located. This weakens the tooth and leads to the initiation and development of the crack at the root filet area. Several solutions have been proposed to deal with the loss of gear teeth. Using the genetic algorithm (GA) for a restricted bending strength, YOKOTA proposed an optimal weight design problem of the gear [1]. Marjanovic investigated optimal material selection, optimal gear ratio, and optimal shaft axis locations using C++ programming [2]. Reddy used the advanced optimization technique, Genetic Algorithm (GA), to determine the optimal combination of design parameters for a gear train's minimum weight. According to the results, the Genetic Algorithm provided better solutions for gear design [3]. Using MATLAB, Sa'id Golabi, Javad Jafari Fesharaki, and Maryam Yazdipoor [4] created a general form of objective function and design constraints for the volume/weight of a gearbox. All of the gearbox's necessary parameters, such as the number of stages, modules, gear face width, and shaft diameter, can be derived from the graphs. Hulusi Delibaş, Çağrı Uzay, and Necdet Geren [5] investigated optimum materials for specific spur gear designs using an advanced material selection technique called Ashby's method, which was used to determine suitable materials based on their material index. The objective function was set to minimize mass based on bending strength, while the constraint was the bending fatigue failure criteria. In terms of costs, a machine tool or automobile should be lighter in weight and consume less power or fuel. Hence, an optimal gear pair for efficient performance is required. The best spur gear drive design was discussed in this study. 
In order to optimize the spur gear drive design, the design specific variable (module, gear thickness, and number of teeth) must be determined. Several design constraints, such as bending stress, compressive stress, module and center distance, and so on, should be considered when designing a gear drive.

\section{PROBLEM DESCRIPTION}

The problem was the implementation of a basic speed reducer, as shown in Figure (1). It is a simple mechanical system with a variety of industrial applications that can accurately transfer power between two shafts. In this regard, we would be concerned with the minimum weight geometry problem of a one-stage spur gearbox while keeping the following constraints in mind:

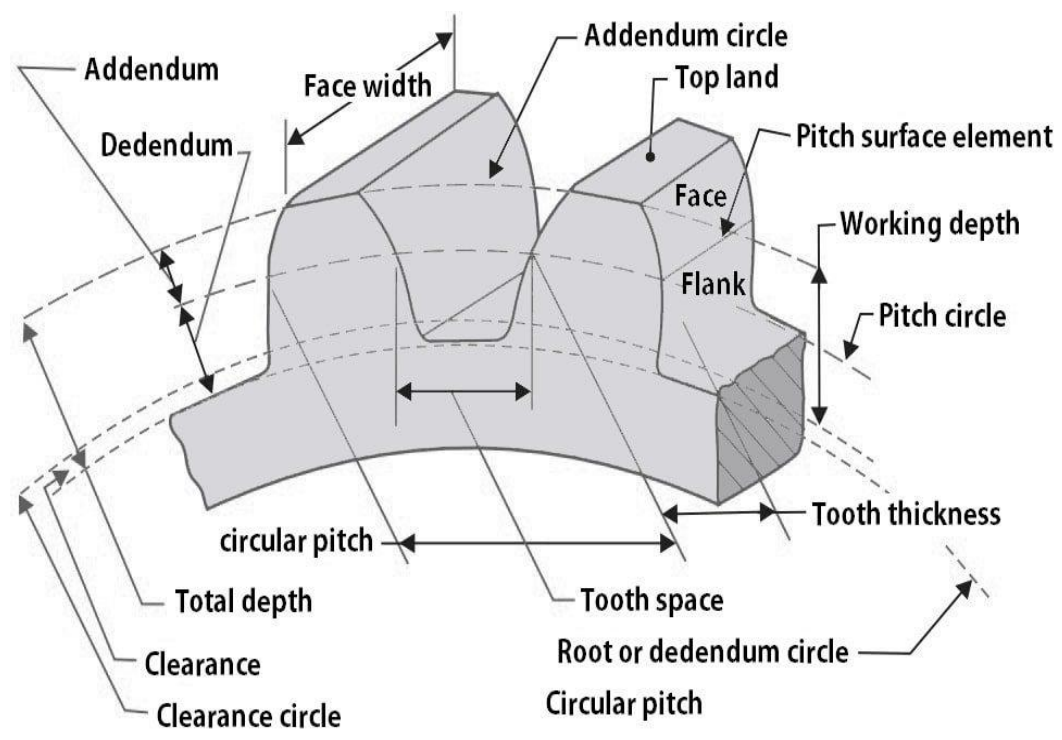

Figure 1: Spur Gear Terminology

The main design variables were: $\mathrm{x}=\left(\mathrm{b}, \mathrm{d}_{1}, \mathrm{~d}_{2}, \mathrm{Z}_{1}, m\right.$ and $\left.\mathrm{Y}\right)$

- face width $b$,

- diameters of pinion and gear shafts $\left(\mathrm{d}_{1}, \mathrm{~d}_{2}\right)$,

- the number of teeth $Z_{1}$ of the pinion,

- gear module ( $m)$.

- Note that $Z_{1}$ is an integer and (m) should take discrete values.

- Lewis Form Factor (Y)

\section{METHODOLOGY}

Gears can be made from a wide range of materials. Furthermore, new materials such as composites can be selected. Engineers now have access to a large number of materials: 160,000 or more [6].

The performance of a structural element is determined by the functional requirements, geometry, and material properties of the structure [1] and [3]. 


$$
\boldsymbol{P}=\left[\left(\begin{array}{c}
\text { Functional } \\
\text { Requirement, F }
\end{array}\right),\left(\begin{array}{c}
\text { Geometric } \\
\text { Parameters, } \mathbf{G}
\end{array}\right),\left(\begin{array}{c}
\text { Material } \\
\text { Properties, } \boldsymbol{M}
\end{array}\right)\right]
$$

(1)

Where $\boldsymbol{P}$ is the performance of a structural element that describes the performance of the component such as its mass, volume, cost, or life. Optimal design is the selection of material and geometry that maximizes or minimizes its desirability.

\section{PROPOSED APPROACH}

The purpose of this study was to create a spur gear with the goal of minimizing the gear's weight based on the parameters of its design. Additionally, the optimization should be performed using a technique that supports mixed variables. Wilfred Lewis proposed an equation for estimating the bending stress in gear teeth in which the tooth form entered into the formulation. The equation, which was published in 1892, is still used to design most gears today [7] (see Figure (2) and Table (1)). The spur gear in this work was designed to meet the bending stress failure criteria. In order to approach the bending stress $\left(\sigma_{b}\right)$ with fatigue strength $\left(F_{s}\right)$ on the spur gear, the tooth must be equal or smaller than gear material.

Table 1: Values of Lewis Form Factor (Y)

\begin{tabular}{|c|c|c|c|}
\hline $\begin{array}{c}\text { Number } \\
\text { of Teeth }\end{array}$ & $\mathbf{Y}$ & $\begin{array}{c}\text { Number } \\
\text { of Teeth }\end{array}$ & $\mathbf{Y}$ \\
\hline 12 & 0.245 & 28 & 0.353 \\
\hline 13 & 0.261 & 30 & 0.359 \\
\hline 14 & 0.277 & 34 & 0.371 \\
\hline 15 & 0.290 & 38 & 0.384 \\
\hline 16 & 0.296 & 43 & 0.397 \\
\hline 17 & 0.303 & 50 & 0.409 \\
\hline 18 & 0.309 & 60 & 0.422 \\
\hline 19 & 0.314 & 75 & 0.435 \\
\hline 20 & 0.322 & 100 & 0.447 \\
\hline 21 & 0.328 & 150 & 0.460 \\
\hline 22 & 0.331 & 300 & 0.472 \\
\hline 24 & 0.337 & 400 & 0.480 \\
\hline 26 & 0.346 & Rack & 0.485 \\
\hline
\end{tabular}

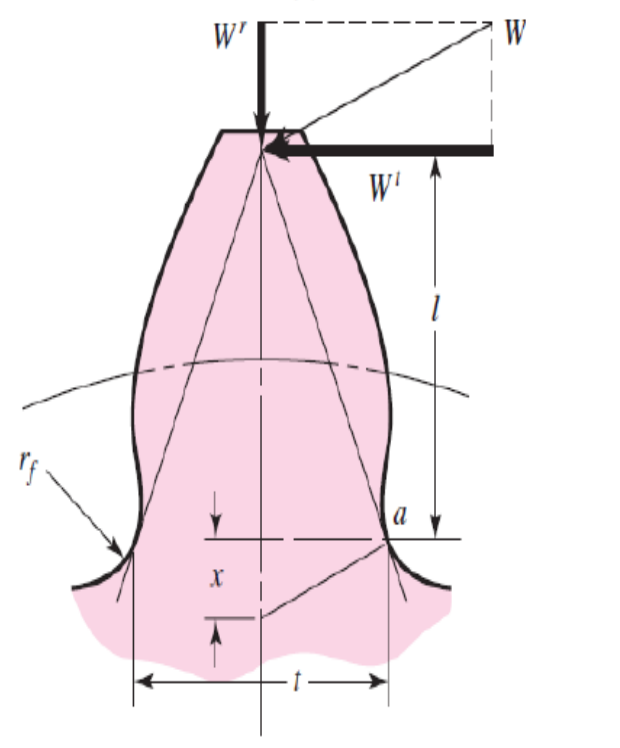

Figure 2: Position of the Applied Forces on Gear Tooth Due to Lewis Approach 


$$
\begin{aligned}
& \sigma_{b} \leq F_{s} \\
& \sigma_{b}=\frac{K_{v} \quad W^{t}}{b \quad m \quad Y} \\
& \mathrm{~V}=\frac{\pi \mathrm{dn}}{60} \\
& \mathrm{~d}=m \mathrm{Z} \\
& \mathrm{K}_{\mathrm{v}}=\frac{6.1+\mathrm{V}}{6.1}
\end{aligned}
$$

Where, $\mathrm{K}_{\mathrm{v}}=$ Dynamic factor, $\mathrm{W}^{\mathrm{t}}=$ Transmitted Torque $(\mathrm{N}-\mathrm{m})$, and $\mathrm{V}=$ Pitch-line velocity $(\mathrm{m} / \mathrm{min})$.

\section{Objective Function for the Spur Gear Design}

A gear wheel is modelled here as a cylinder, which is a fairly accurate approximation. A spur gear's mass (M) can be approximated as the mass of a cylinder whose radius and height are half of the pitch diameter and face width of the spur gear, respectively [8]. Thus, the mass $(M)$ of one spur gear is as follows:

$$
\begin{aligned}
& \operatorname{Mass}(M)=\text { Volume of cylinder } * \text { Density } \\
& M=\pi \mathrm{b} \mathrm{r}^{2} \rho
\end{aligned}
$$

Where $\mathbf{b}$ is the face width, $\boldsymbol{r}$ is the reference radius, and $\boldsymbol{\rho}$ is the mass density of the wheel.

$3 \pi m \leq \mathrm{b} \leq 5 \pi m(8)$

$$
\begin{aligned}
& \text { Where } \quad 3 \leq \mathrm{C}_{1} \leq 5 \quad \text { (where } \mathrm{C}_{1} \text { is constant) } \\
& \mathrm{b}=\mathrm{C}_{1} \pi m \\
& \mathrm{~d}=m \mathrm{Z} \\
& \text { then } \quad 2 \mathrm{r}=m \mathrm{Z}
\end{aligned}
$$

By substituting equations (9) and (10) into equation (7), equation (11) is obtained.

$$
M=C_{1} \frac{\pi^{2}}{4} Z^{2} m^{3} \rho
$$

In this research, some of the candidate materials for spur gear design were selected, and the properties of the selected candidate materials were listed in Table 2. 
Table 2: Properties of the Selected Candidate Materials

\begin{tabular}{|c|l|c|c|c|c|}
\hline No. Material & $\begin{array}{c}\text { Density } \\
\text { Kg/m3 }\end{array}$ & $\begin{array}{c}\text { Modulus of } \\
\text { Elasticity } \\
\text { GPa }\end{array}$ & Poission Ratio & $\begin{array}{c}\text { Strength } \\
\text { MPa }\end{array}$ \\
\hline METALS & \multicolumn{5}{l|}{} \\
\hline 1 & Steel & 7800 & 200 & 0.32 & 1724 \\
\hline 2 & Aluminium & 2700 & 69 & 0.33 & 483 \\
\hline 3 & Titanium & 4500 & 91 & 0.36 & 758 \\
\hline \multicolumn{5}{|c|}{ FIBERS ( Axial Properties ) } \\
\hline 4 & AS4 & 1800 & 235 & 0.20 & 3599 \\
\hline 5 & T300 & 1760 & 231 & 0.20 & 3654 \\
\hline 6 & P100S & 2150 & 724 & 0.20 & 2199 \\
\hline 7 & IM8 & 1800 & 310 & 0.20 & 5171 \\
\hline 8 & Boron & 2600 & 385 & 0.21 & 3799 \\
\hline 9 & Kevlar 49 & 1440 & 124 & 0.34 & 3620 \\
\hline 10 & SCS-6 & 3300 & 400 & 0.25 & 3496 \\
\hline 11 & Nicalon & 2550 & 180 & 0.25 & 2000 \\
\hline 12 & S-2 Glass & 2460 & 86.8 & 0.23 & 4585 \\
\hline 13 & E-Glass & 2580 & 69 & 0.22 & 3450 \\
\hline \multicolumn{7}{|l|}{ MATRIX MATERIALS } & & 400 \\
\hline 14 & Copper & 8900 & 117 & 0.33 & 310 \\
\hline 15 & Silicon Carbide & 3200 & 400 & 0.25 & \\
\hline
\end{tabular}

The design problem's requirements are shown in Table (3). The design of gears was done based on the requirements. And the calculation of spur gear parameters are listed in Table (4).

Table 3: Requirements of the Spur Gear Design Problem

\begin{tabular}{|l|l|}
\hline \multicolumn{1}{|c|}{ Parameters } & \multicolumn{1}{c|}{ Value } \\
\hline Gear tooth geometry & Standard interference free, involute spur, full depth teeth \\
\hline Pressure angle, $\emptyset$ & $20^{\circ}$ \\
\hline Input speed of power source $\mathrm{n}_{1}$ & $2100 \mathrm{rpm}$ \\
\hline Output speed $\mathrm{n}_{2}$ & $700 \mathrm{rpm}$ \\
\hline Transmitted power $(\mathrm{P})$ & $10 \mathrm{KW}$ \\
\hline Number of life cycles & $10,000,000$ \\
\hline Design criteria & Based on bending Lewis equation \\
\hline
\end{tabular}

Table 4: Calculation of Gear Parameters

\begin{tabular}{|l|c|c|}
\hline \multicolumn{1}{|c|}{ Specification } & ISO-Symbol & \multicolumn{1}{c|}{ Formulas } \\
\hline Pitch Circle Diameter & $\mathrm{d}$ & $\mathrm{m} \mathrm{Z}$ \\
\hline Outside Circle Diameter & $\mathrm{d}_{\mathrm{o}}$ & $(\mathrm{Z}+2)^{*} \mathrm{~m}$ \\
\hline Circular Pitch & $\mathrm{P}_{\mathrm{c}}$ & $\pi \mathrm{m}$ \\
\hline Base Circle Diameter & $\mathrm{D}_{\mathrm{B}}$ & $\mathrm{dp} * \cos \varnothing$ \\
\hline Clearance & $\mathrm{Cl}$ & $\frac{\text { circular pitch }}{20}$ \\
\hline Addendum & $\mathrm{A}_{\mathrm{dd}}$ & $\mathrm{m}$ \\
\hline Dedendum & $\mathrm{D}_{\mathrm{ed}}$ & $\mathrm{m}+$ clearance \\
\hline Addendum circle diameter & $\mathrm{D}_{\mathrm{A}}$ & $\mathrm{dp}-(2 *$ Addendum $)$ \\
\hline Fillet Radius & $\mathrm{R}_{\mathrm{f}}$ & $\frac{\text { circular pitch }}{8}$ \\
\hline Center distance & $\mathrm{a}$ & $(\mathrm{dp} 1+\mathrm{dp} 2) / 2$ \\
\hline Face width & $\mathrm{b}$ & $5 \mathrm{~d}$ \\
\hline
\end{tabular}


An iterative process was used in Spur gear design (MATLAB), as shown in the results in Table (5). The software generated two key values: first, a starting module was estimated until the boundary condition was approached and it was iterated until the face width (b) was obtained in an acceptable range [5] and [9]. The Lewis equation [10], as shown in equation (3), was used to calculate (m) and (b) values. Second, the iteration process was continued to determine the minimum value of gear weight using equation (11), with 924 iterations for each material to determine the best module $(m)$.

Table 5: Results of MATLAB Programme to Estimate the Minimum Weight of Spur Gears

\begin{tabular}{|c|l|c|c|c|c|}
\hline No. & Material & $\begin{array}{c}\text { Module }(\mathbf{m}), \\
\mathbf{m m}\end{array}$ & $\begin{array}{c}\text { Face Width } \\
(\mathbf{b}), \mathbf{m m}\end{array}$ & $\begin{array}{c}\text { Weight, Kg } \\
(\mathbf{M})\end{array}$ & $\begin{array}{c}\text { Ranking Depends on the } \\
\text { Minimum Weight of Gears }\end{array}$ \\
\hline 1 & Steel & 1.50 & 20.93 & 8.17 & 13 \\
\hline 2 & Aluminium & 2.00 & 31.98 & 5.56 & 11 \\
\hline 3 & Titanium & 2.00 & 27.52 & 7.32 & 4 \\
\hline 4 & AS4 & 1.00 & 16.37 & 1.25 & 3 \\
\hline 5 & T300 & 1.00 & 16.29 & 1.22 & 2 \\
\hline 6 & P100S & 1.25 & 19.30 & 1.97 & 6 \\
\hline 7 & IM8 & 1.00 & 14.51 & 1.02 & $\mathbf{1}$ \\
\hline 8 & Boron & 1.00 & 16.08 & 1.75 & 10 \\
\hline 9 & Kevlar 49 & $\mathbf{1 . 0 0}$ & $\mathbf{1 6 . 3 4}$ & $\mathbf{0 . 9 9}$ & 5 \\
\hline 10 & SCS-6 & 1.25 & 16.53 & 2.33 & 7 \\
\hline 11 & Nicalon & 1.25 & 19.92 & 2.46 & 15 \\
\hline 12 & S-2 Glass & 1.00 & 15.11 & 1.49 & 14 \\
\hline 13 & E-Glass & 1.25 & 16.61 & 1.84 & \\
\hline 14 & Copper & 2.25 & 34.06 & 20.12 & \\
\hline 15 & Silicon & 2.50 & 37.08 & 8.23 & \\
\hline
\end{tabular}

For more details of MATLAB program see Figure (3) depicts the software's procedures. 


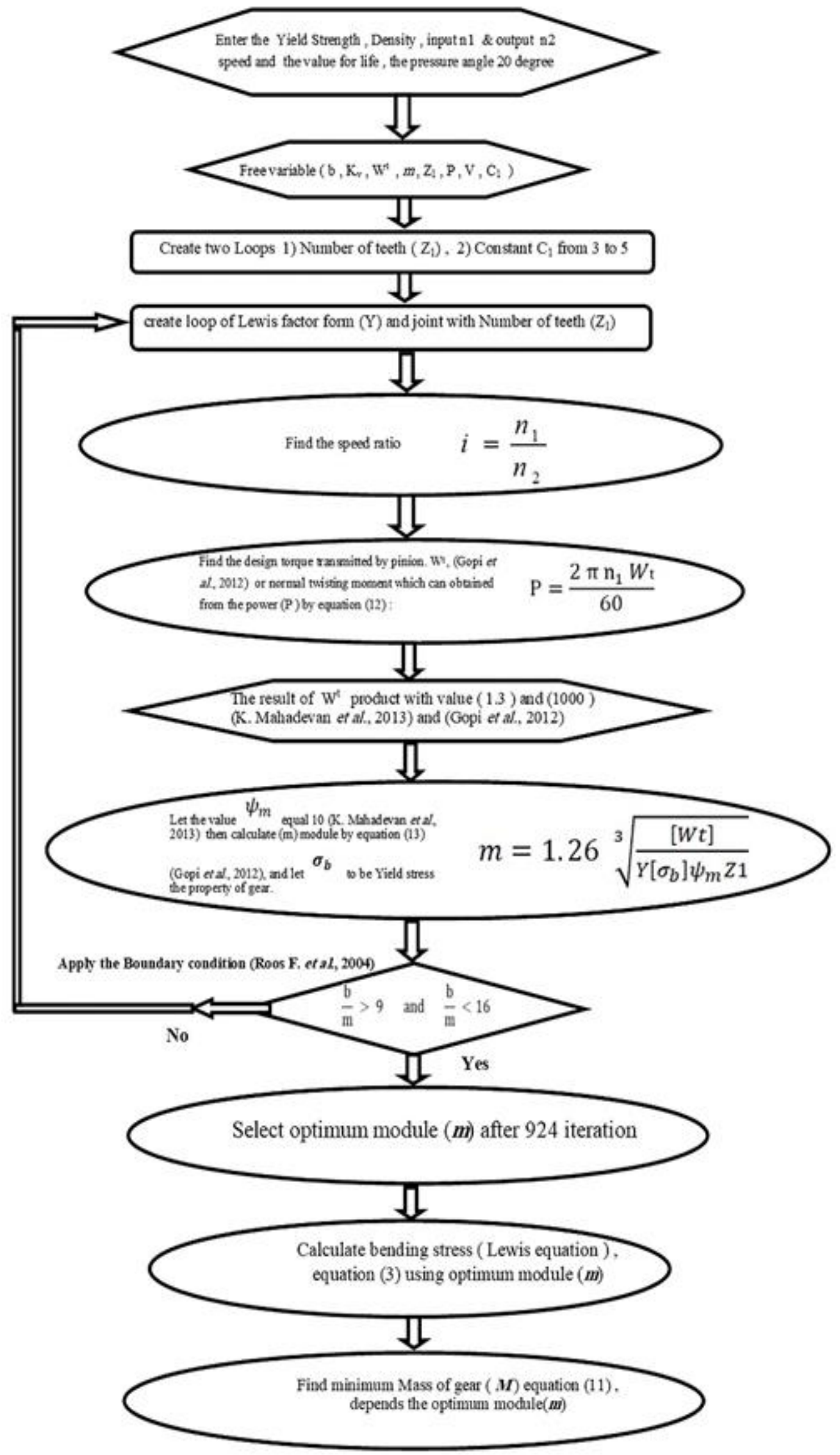

Figure 3: Process of flowchart of MATLAB 
Minimum Weight Optimization of Materials and High Strength for Spur Gear Design

Other gear parameters such as addendum, dedendum, and center distance determination, as well as pitch circle diameter, were evaluated. Following the estimation of the optimum module $(\mathrm{m})$, the necessary terms were calculated and the basic spur gear terms were indicated, as shown in Table (4).

\section{RESULTS AND DISCUSSIONS}

\subsection{Estimation of minimum weight of spur gear}

Metals, fibers (Axial Properties), and matrix materials were used in the spur gear design's 15 different materials. Table 5 displays the weight $(M)$, module $(m)$, and face width $(\mathrm{b})$ results for the selected materials. The weight of the gears is shown in the last two columns of Table 5, along with its ranking as the lightest gear weight. Steel, Silicon Carbide, and copper are relatively heavy due to their widespread use as gear materials. However, the heaviest recommended material (Kevlar 49, estimated weight $0.99 \mathrm{~kg}$ ) was discovered to be approximately $13 \%$ lighter than steel. The weight reduction for the other recommended materials, Kevlar 49 and IM8, when compared to steel, was approximately 22\% and 34\%, respectively. This result showed that the fibers of the component type (Axial Properties) are lighter than others.

The weight relation of the gears with either module $(m)$ or face width is shown in Table (5) and is an inverse relationship that, as shown in Figure (4) and Figure (5), increases the speed while decreasing the width of the module and face see Table (6).

Table 5: Results of MATLAB Programme to Estimate Minimum Weight of Spur Gears

\begin{tabular}{|c|l|c|c|c|c|}
\hline No. & \multicolumn{1}{|c|}{ Material } & $\begin{array}{c}\text { Module } \\
(\mathbf{m}), \mathbf{m m}\end{array}$ & $\begin{array}{c}\text { Face width } \\
(\mathbf{b}) \mathbf{m m}\end{array}$ & $\begin{array}{c}\text { Weight, Kg } \\
\mathbf{( M )}\end{array}$ & $\begin{array}{c}\text { Ranking Depends on the } \\
\text { Minimum Weight of Gears }\end{array}$ \\
\hline 1 & Steel & 1.50 & 20.93 & 8.17 & 13 \\
\hline 2 & Aluminium & 2.00 & 31.98 & 5.56 & 11 \\
\hline 3 & Titanium & 2.00 & 27.52 & 7.32 & 4 \\
\hline 4 & AS4 & 1.00 & 16.37 & 1.25 & 3 \\
\hline 5 & T300 & 1.00 & 16.29 & 1.22 & 8 \\
\hline 6 & P100S & 1.25 & 19.30 & 1.97 & 6 \\
\hline 7 & IM8 & 1.00 & 14.51 & 1.02 & $\mathbf{1}$ \\
\hline 8 & Boron & 1.00 & 16.08 & 1.75 & 9 \\
\hline 9 & Kevlar 49 & $\mathbf{1 . 0 0}$ & $\mathbf{1 6 . 3 4}$ & $\mathbf{0 . 9 9}$ & 10 \\
\hline 10 & SCS-6 & 1.25 & 16.53 & 2.33 & 5 \\
\hline 11 & Nicalon & 1.25 & 19.92 & 2.46 & 15 \\
\hline 12 & S-2 Glass & 1.00 & 15.11 & 1.49 & 14 \\
\hline 13 & E-Glass & 1.25 & 16.61 & 1.84 & \\
\hline 14 & Copper & 2.25 & 34.06 & 20.12 & \\
\hline 15 & Silicon Carbide & 2.50 & 37.08 & 8.23 & \\
\hline
\end{tabular}




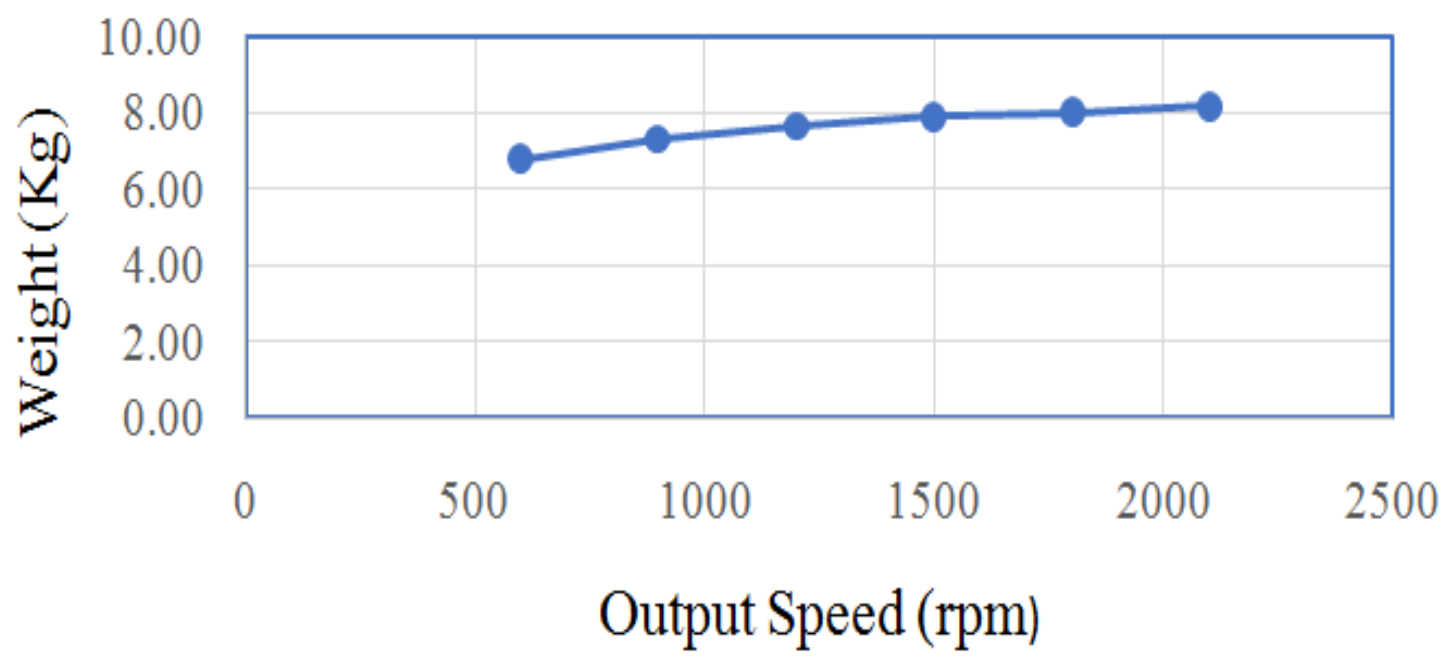

Figure 4: Relation between Output Speed and Weight of Gear

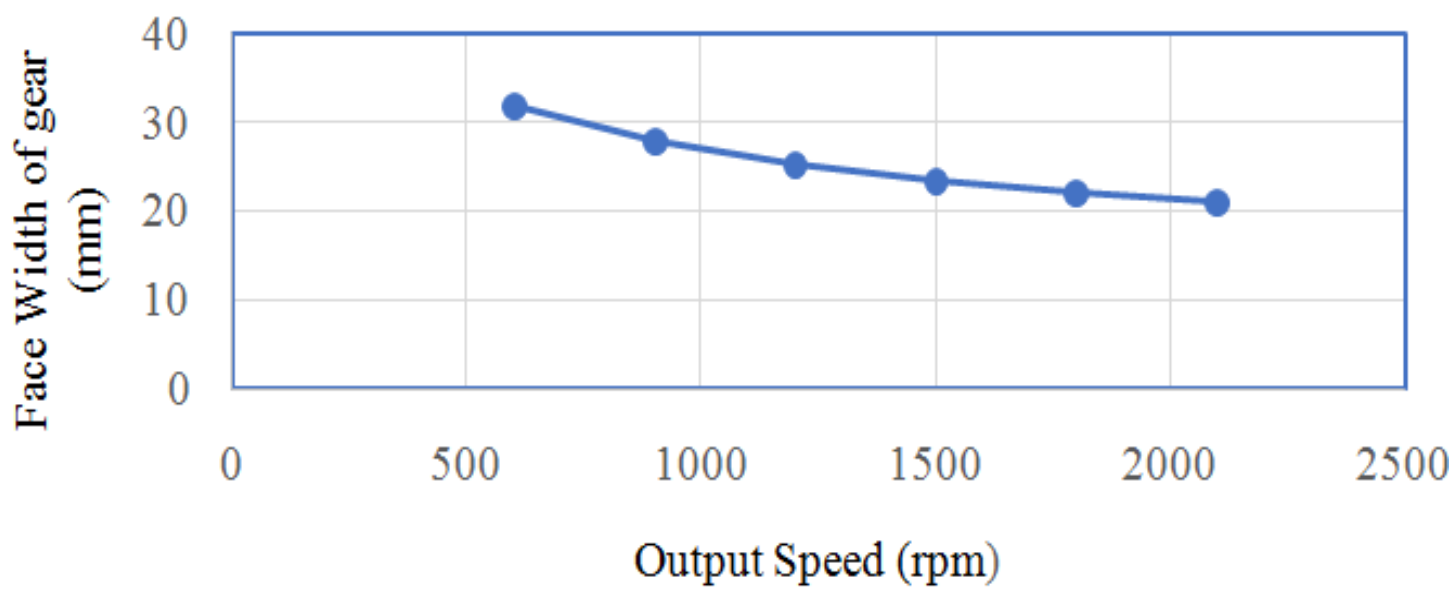

Figure 5: Relation between Output Speed and Face Width of Gear

Table 6: Results of MATLAB for Different Speeds of Input and Output for Steel

\begin{tabular}{|c|c|c|c|c|c|c|}
\hline \multicolumn{7}{|c|}{ Material: Steel with ratio $1 / 3$} \\
\hline $\begin{array}{c}\text { Speed } \\
\text { (input/output) }\end{array}$ & $\begin{array}{l}\text { 200/600 } \\
\text { rpm }\end{array}$ & $\begin{array}{l}\text { 300/900 } \\
\text { rpm }\end{array}$ & $\begin{array}{l}\text { 400/1200 } \\
\text { rpm }\end{array}$ & $\begin{array}{l}\text { 500/1500 } \\
\text { rpm }\end{array}$ & $\begin{array}{l}\text { 600/1800 } \\
\text { rpm }\end{array}$ & $\begin{array}{c}700 / 2100 \\
\text { rpm }\end{array}$ \\
\hline Weight, $\mathrm{Kg}$ & 6.77 & 7.30 & 7.64 & 7.87 & 8.00 & 8.17 \\
\hline Module, $\mathrm{mm}$ & 2.12 & 1.85 & 1.68 & 1.56 & 1.46 & 1.39 \\
\hline Width, mm & 31.77 & 27.76 & 25.22 & 23.41 & 22.03 & 20.93 \\
\hline
\end{tabular}

\subsection{Finite Element Analysis by ANSYS}

The FEA results proved that simulation software, such as ANSYS, could predict a high percentage of gear failure, lowering the cost of practical prototypes. To validate the spur gear design data, a numerical simulation was performed using ANSYS R17 and finite element analysis (FEA). The static structural module was used under static load forces. The FEA analysis were performed in three steps,

- Modelling and pre-processing: part modelling, assigning material properties, meshing (number of Nodes 16750 , number of Elements 2448) and applying loads and boundary conditions (see Figures (6)). 
- Solving: Preparing and solving the linear equation of an element.

- $\quad$ Post-Processing: Generating the results as graphs, tables or animations under different materials.

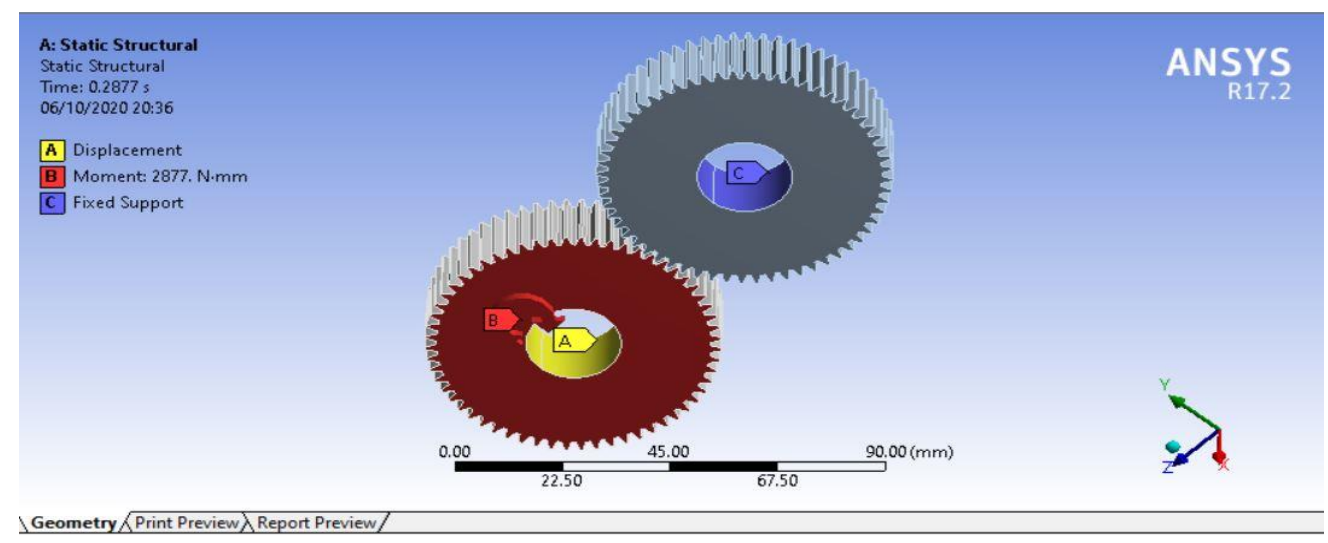

Figure 6: Boundary Condition of Ansys between Two Involute Teeth.

The first step was to create a 3D geometry of the spur gear specimens in SOLIDWORKS. The model was then imported into ANSYS, and the constituents' material properties were listed in Table (2). After attaching the geometry to the Static Structural Analysis tab, the next step was to define the contact between the two involute teeth.

- Boundary condition: ANSYS has an inbuilt option, which automatically reads the attached geometry for any predefined contacts or other boundary definitions. The contact between the two teeth is assumed to be frictionless; The detailed frictionless contact between the gear pairs is shown in Figure (6) below. One of the most important things to do is to change the "Interface Treatment" to "Adjust to touch". This option defines the kind of contact between the selected bodies.

Furthermore, with Kevlar 49 material, contact and bending stresses, as well as total deformation of the gear over the flank and root of the gear teeth, meet the requirement to operate at minimum service life. The use of various materials in gear manufacturing results in a variety of contact and bending stresses. This range of contact stresses and bending stresses is useful in material selection for various applications. The use of various materials in gear manufacturing results in a variety of contact stresses, which are tabulated in Figure 7. 


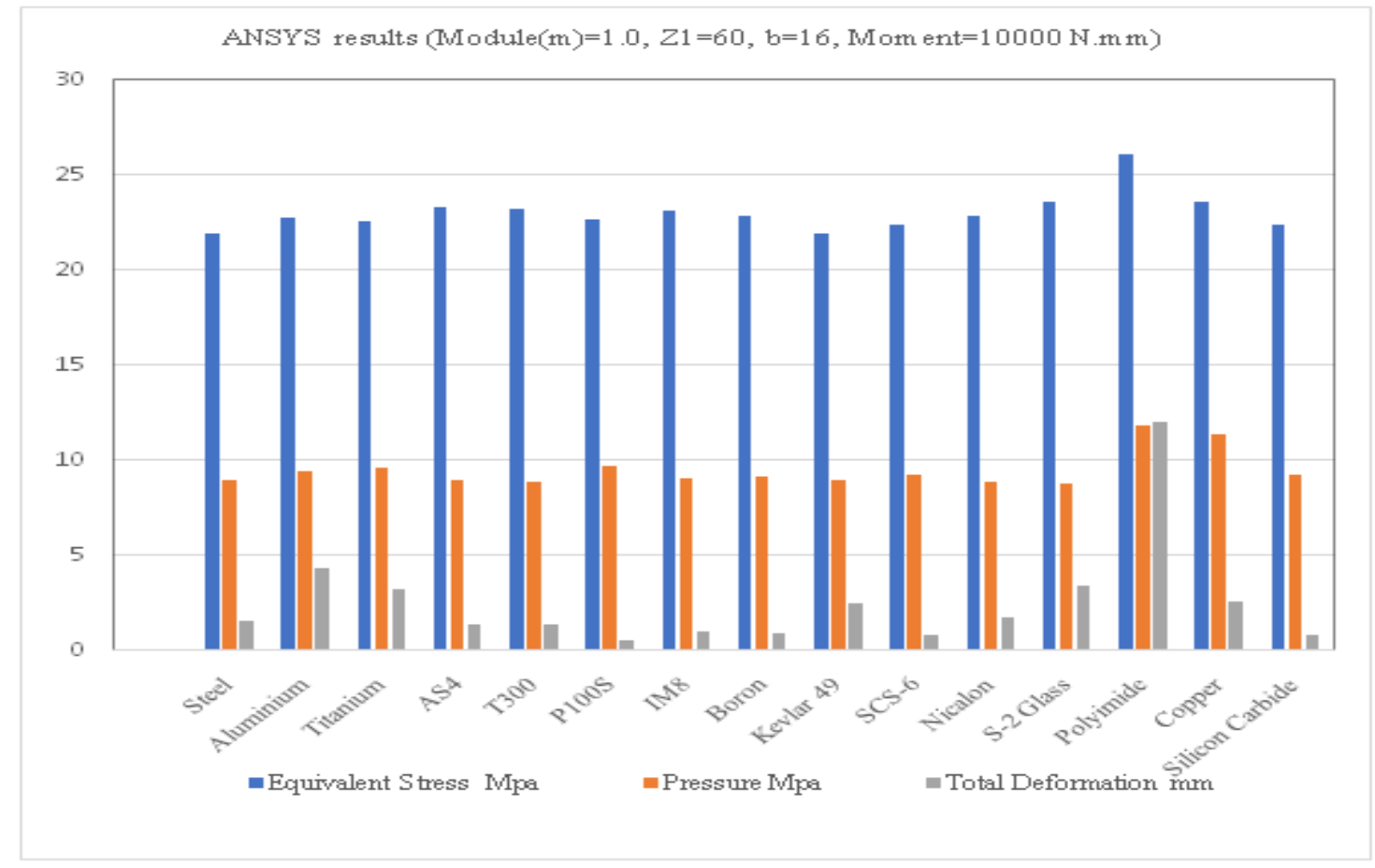

Figure 7: Results of Finite Element Analysis (ANSYS) for Selected Materials

Figure (8) shows that the pressure (contact stress) of Kevlar 49 is $8.95 \mathrm{MPa}$ and the bending stress (Equivalent Stress) is $21,9 \mathrm{MPa}$ when compared to steel, which has the same values but the weight of steel is $8.17 \mathrm{Kg}$ while the weight of Kevlar is $0.99 \mathrm{Kg}$ under the same conditions.

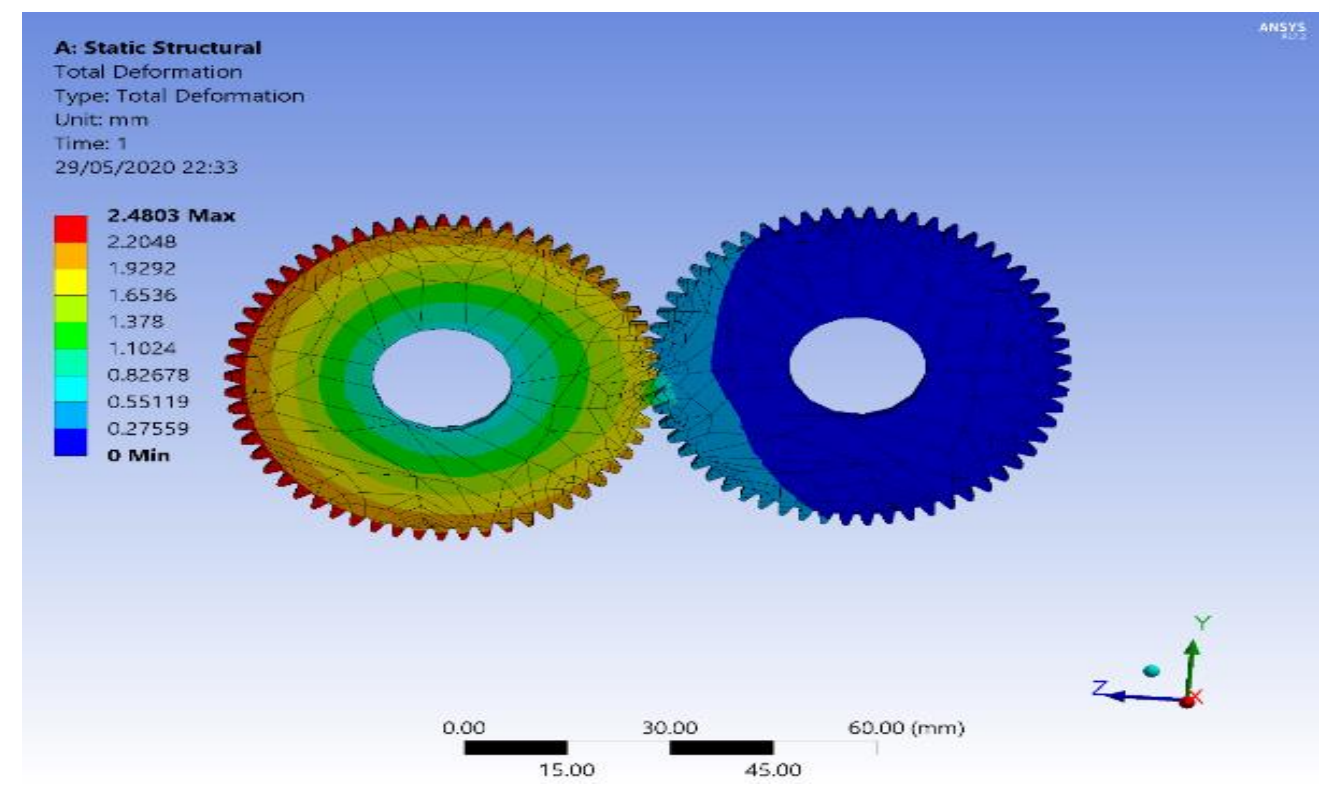

a) Total deformation $=2.48 \mathrm{~mm}$ 


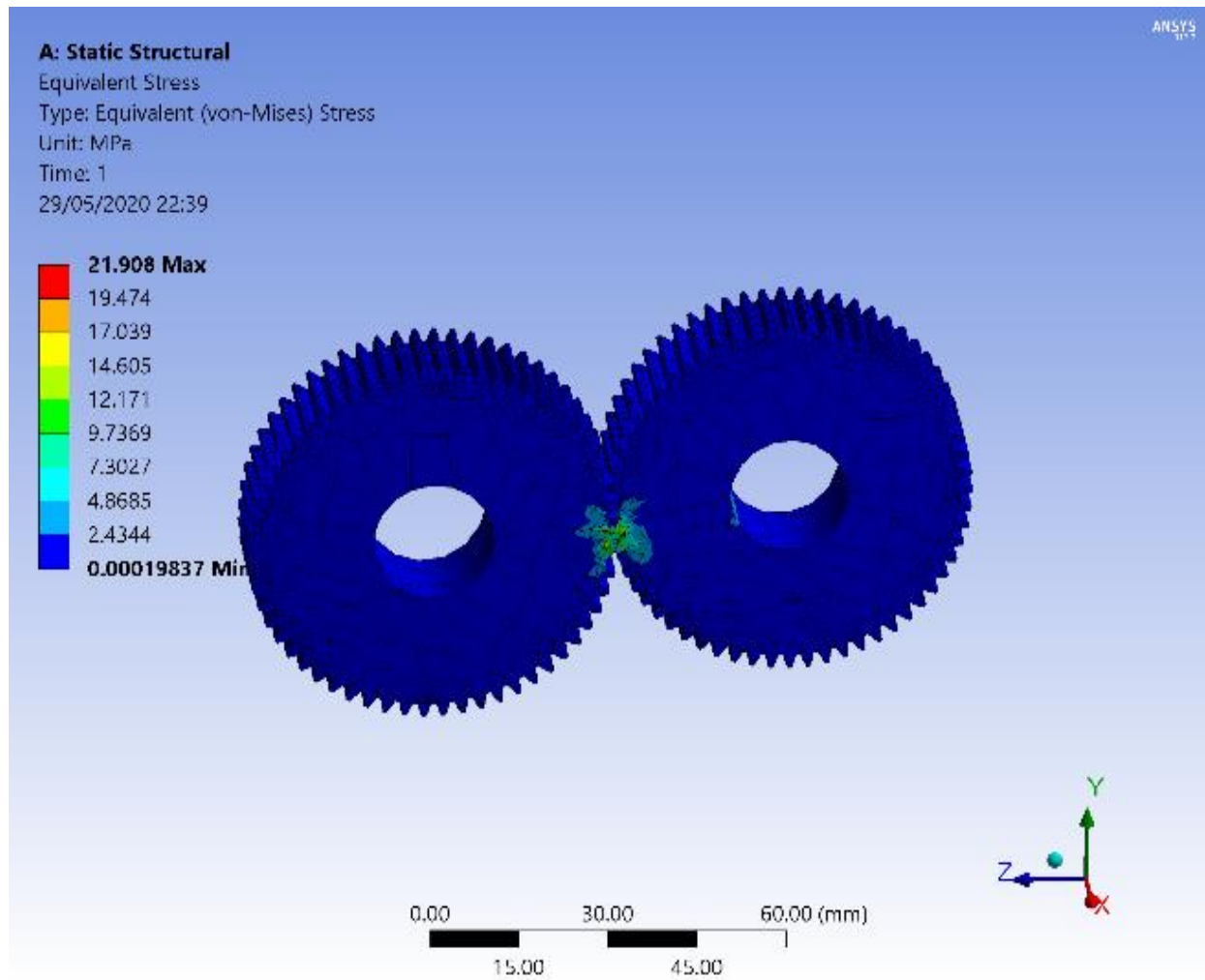

b) Equivalent Stress =21.9 MPa

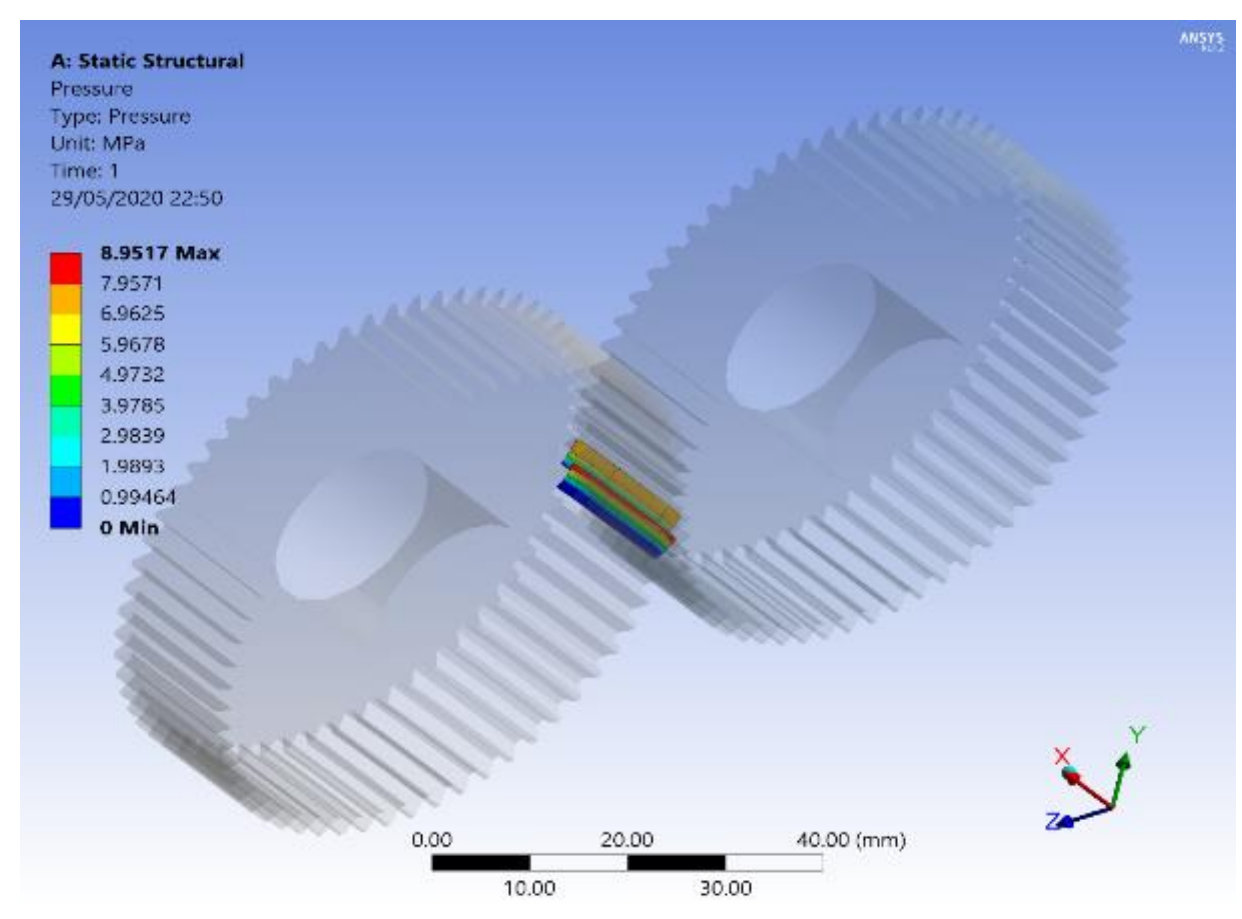

b) Pressure $=8.95 \mathrm{Mpa}$ 


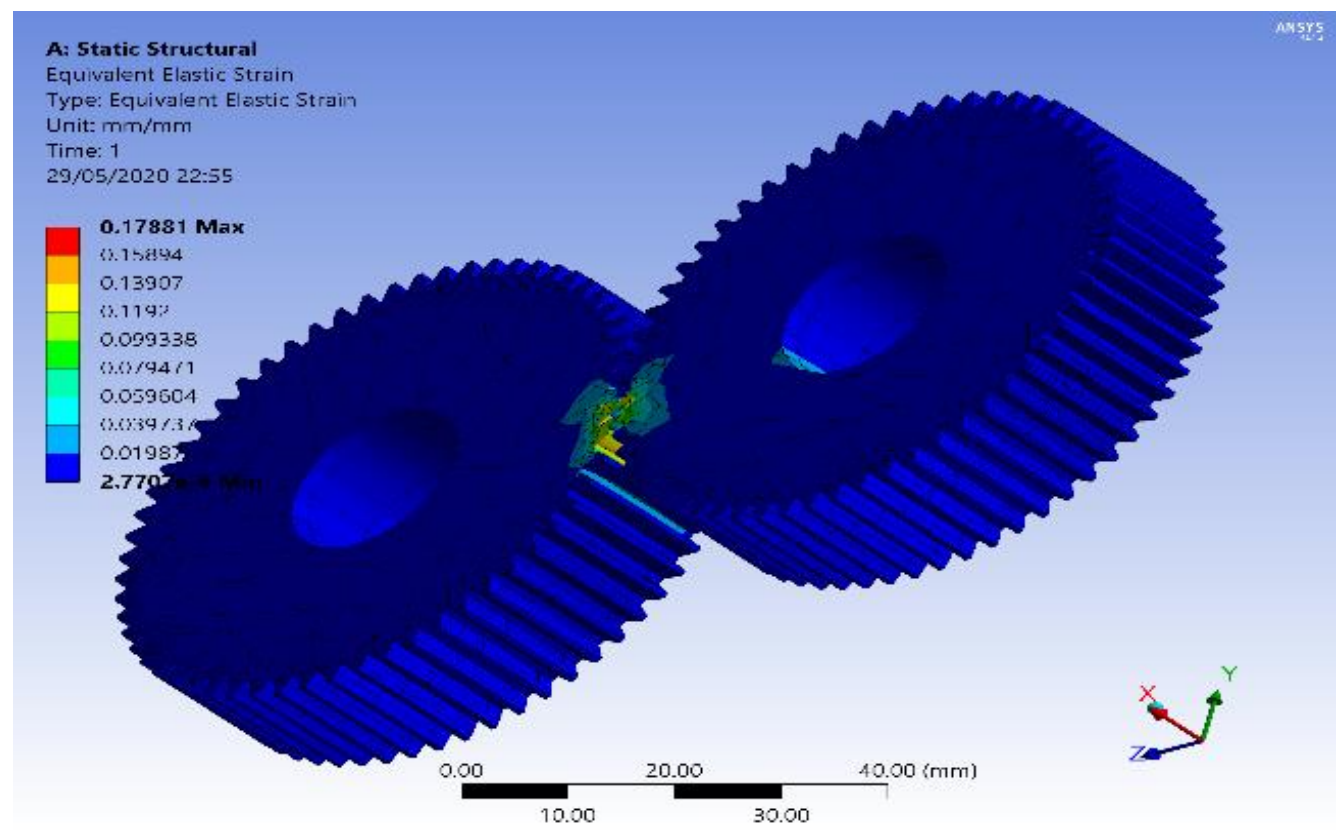

d) Equivalent Elastic Strain=0.178

Figure (8 a, b, c, d): Material of Kevlar 49

\section{CONCLUSIONS}

The module is a necessary component of the spur gear parameters for determining the minimum gear weight.

- The (Fibers) composite material (Kevlar 49) can be used in the manufacture of spur gear rather than steel material because it has been demonstrated that composite material has less displacement and stress induced on the application of increasing torque load condition.

- The use of composite materials such as Kevlar 49 reduces the weight of the spur gears, which is a plus. As a result, composite (Kevlar 49) spur gears outperform steel spur gears in terms of reliability.

- The design software problem was useful to approach in order to confirm the material selection prior to conducting the material experimental tests.

- According to the results of finite element analysis, the software gear design is more precisely related (ANSYS).

- The weight reduction for the other recommended materials, Kevlar 49 and IM8, when compared to steel, was approximately $22 \%$ and $34 \%$, respectively.

- The gear design software was useful in eliminating a large number of materials before selecting the materials.

\section{ACKNOWLEDGMENTS}

This study was mainly supported by the Department of Mechanical \& Mechatronics Engineering, College of Engineering, Salahaddin University-Erbil, Ministry of Higher Education and Scientific Research, Kurdistan Regional Government(KRG), Iraq. And support from the laboratory of Faculty of Mechanical Engineering, Department of Mechanics \& Fluiddynamic, Technical University Freiberg, Germany. 


\section{REFERENCES}

1. Yokota, T., T. Taguchi, and M. Gen, A solution method for optimal weight design problem of the gear using genetic algorithms. Computers \& industrial engineering, 1998. 35(3-4): p. 523-526.

2. Marjanovic, N., et al., A practical approach to the optimization of gear trains with spur gears. Mechanism and Machine Theory, 2012. 53: p. 1-16.

3. Reddy, B.H., J.S. Kumar, and A.H. Babu, Minimum Weight Optimization of a Gear Train by using Genetic Algorithm. Int. J. Current. Eng. Tech, 2016. 6(4): p. 1119-1124.

4. Golabi, S.i., J.J. Fesharaki, and M. Yazdipoor, Gear train optimization based on minimum volume/weight design. Mechanism and machine theory, 2014. 73: p. 197-217.

5. Delibaş, H., U. Çăgrt, and N. Geren, Advanced material selection technique for high strength and lightweight spur gear design. European Mechanical Science, 2017. 1(4): p. 133-140.

6. Ashby, M.F. and D. CEBON, Materials selection in mechanical design. Le Journal de Physique IV, 1993. 3(C7): p. C7-1-C79.

7. Houser, D.R., Helix Angle and Root Stress. Gear Solutions, 2012. 10(107): p. 30-41.

8. Roos, F. and C. Spiegelberg, Relations between size and gear ratio in spur and planetary gear trains. 2005: KTH.

9. Sainath, I.A., Design of Spur Gear and its Tooth profile. Journal of Engineering Research and Applications (IJERA) ISSN. 2248: p. 9622.

10. Krishnan, V., Dr. Ravi V Mr. Nagesh SN Dr. Tulasidas TN Mr. Vishwanth Koti. Dr. A. Sathyanarayana Swamy Ms. Jyothilakshmi R. Dr. ND Prasanna Mr. C. Siddaraju Dr. Raji George Mr. Anil Kumar T.

11. Aru, Suraj, et al. "Design and Analysis of Centrally Suspended Cage-Less Differential." International Journal of Mechanical and Production Engineering Research and Development 4.4 : 49-60.

12. Oleiwi, Jawad K., and Ahmed Namah Hadi. "Experimental and numerical investigation of lower limb prosthetic foot made from composite polymer blends." International Journal of Mechanical and Production Engineering Research and Development 8.02 : 1319-1330.

13. Bakar, Mashitah Abu, and Jamali Md Sah. "Dynamic Response Analysis for Development of Flexible Lightweight Vehicle Chassis Using CAE Tools." International Journal of Mechanical Engineering (IJME) 7.3 (2018): 9-20.

14. Nireekshana, T., and V. Ramesh Babu. "Design and Fabrication of linear induction motor for traction application." International Journal of Electrical and Electronics Engineering (IJEEE) 6.6 (2017): 1-18. 